\title{
Immediate effects of a storm on coastal infauna
}

\author{
Fred C. Dobbs and Joseph M. Vozarik*
}

Northeast Utilities Environmental Laboratory, P. O. B. 128, Waterford, Connecticut 06385, USA

\begin{abstract}
Effects of storms on benthic infaunal communities have thus far been inferred rather than documented; especially lacking are studies examining immediate effects. To this end, the water column and 2 subtidal benthic sites were sampled before and after Storm David in September 1979. There were large post-storm increases in the numbers of infaunal species and individuals in the water column, presumably due to turbulent benthic boundary conditions. At the benthic stations, there were no pre vs. post-storm differences in the density of infauna; however, the number of species decreased at 1 station. There were storm-associated changes in the rank order of dominant infaunal taxa although these generally were rearrangements rather than substitutions. Cluster analysis of benthic data showed distinct spatial, but not temporal, groups. Because pre- and post-storm differences in benthic infaunal samples were not commensurate with the magnitude of change in the water column infauna, the storm apparently was more catastrophic to distant infaunal communities. Thus, we suggest that disturbance by storms may be a mechanism for wide post-larval dispersal of ostensibly obligate infauna.
\end{abstract}

\section{INTRODUCTION}

In estuarine and marine environments, storms are a most severe naturally-occurring physical disturbance and are believed to be an important factor in structuring nearshore soft-substrate communities. Although many investigators have invoked storms to explain natural fluctuations in infaunal communities (Eagle, 1975; McCall, 1977, 1978; Wolff et al., 1977; Rachor and Gerlach, 1978; Glémarec, 1979), a cause-effect relationship usually has been inferred rather than demonstrated. Few studies offer fairly rigorous 'beforeafter' data. Boesch et al. (1976) found that following a hurricane, drastic reductions in salinity and dissolved oxygen concentrations eliminated many species and resulted in irruptions of opportunists. Rees et al. (1977) and Yeo and Risk (1979) showed that storm-amplified current and wave action can scour surficial sediments, causing high mortality and redistribution of infauna, especially shallow-burrowing species. In contrast, Barnett (1981) observed 'no dramatic depletion' of intertidal infauna following a 'severe storm'. And Croker (1968) saw 'no obvious changes' in the distribution patterns of haustoriid amphipods following the passage of 2 hurricanes on an intertidal Georgia beach.

\footnotetext{
- Order of authorship was decided by a coin toss
}

In most of the above studies, weeks or months elapsed between collection of before and after samples. In the present investigation, all sampling was completed within $3 \mathrm{~d}$, thus permitting assessment of the immediate effects of a storm on benthic infauna. A comparative sampling approach was taken in light of recent observations and experiments which have shown that non-reproductive and ostensibly obligate infauna regularly occur in the water column (Dexter, 1967; Croker, 1968; Dean, 1978a, b; Graham and Creaser, 1978; Bell and Sherman, 1980; Grant, 1980, 1981; Palmer and Brandt, 1981). Thus, samples for benthic infauna were collected from both bottom sediments and the water column.

\section{MATERIALS AND METHODS}

This study was conducted at the Millstone Nuclear Power Station, Millstone Point, CT, located on the north shore of Long Island Sound (Lat. 41 $18^{\prime} 25^{\prime \prime} \mathrm{N}$ Long. $72^{\circ} 10^{\prime} 00^{\prime \prime} \mathrm{W}$ ) (Fig. 1.). On 6 September 1979 a storm (David) began at $0400 \mathrm{~h}$ and lasted for approximately $20 \mathrm{~h}$. Winds began from the southeast, gradually changed to westerly, and ranged from 17.8 to 63.8 $\mathrm{km} \mathrm{h}^{-1}$. Maximum wind speed the day before the storm was $16.3 \mathrm{~km} \mathrm{~h}^{-1}$. 


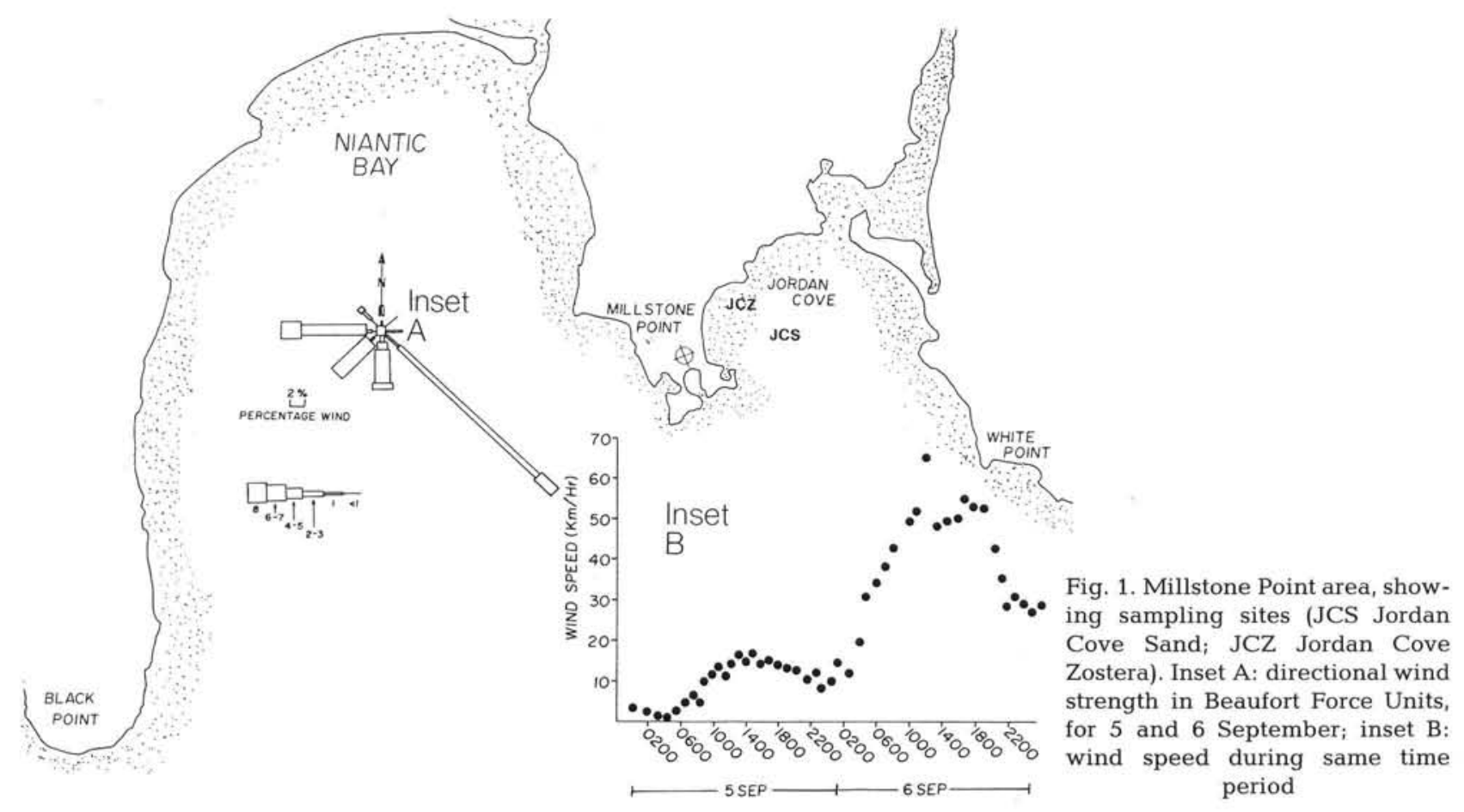

Water column

Water column samples were taken from the power plant's once-through cooling system to assess storm mobilization of benthic infauna. At $2200 \mathrm{~h}$ on both 5 and 6 September (flooding tide, full moon), $400 \mathrm{~m}^{3}$ of effluent were filtered through a $1.0 \mathrm{~m}$ diameter net (0.333 mm mesh). Benthic taxa were sorted, identified to the lowest possible taxon, and counted. In the 6 September sample, crustaceans were too numerous to count and were estimated to represent $75 \%$ (by number) of all organisms sampled.

\section{Bottom sediments}

Two benthic stations were sampled: Jordan Cove Sand (sand), a silty sand site, $5 \mathrm{~m}$ deep, and Jordan Cove Zostera, (Zostera), a Zostera marina bed, 5 to $7 \mathrm{~m}$ deep. On 5 and 7 September, 10 samples were collected from both the sand and Zostera sites (total of 40 cores). Samples were taken by divers using a corer $10 \mathrm{~cm}$ (i.d.) by $5 \mathrm{~cm}$ deep; each core was placed in a separate $0.333 \mathrm{~mm}$ mesh Nitex bag, brought to the surface, returned to the laboratory, and fixed with $10 \%$ buffered formalin (Rose Bengal stain added). After $48 \mathrm{~h}$, organisms were floated from the sediments onto a $0.5 \mathrm{~mm}$ mesh sieve, and the float and residue were separately preserved in $70 \%$ ethanol. Macrofauna were removed under dissecting microscopes, sorted, and identified. Pre- and post-storm values of commu- nity density, number of species, and density of dominant taxa were compared using a nonparametric Wilcoxon $U$ test ( $\alpha=0.0 .5)$. A core $(3.5 \mathrm{~cm}$ i. d. by $5 \mathrm{~cm}$ deep) for sediment analysis was collected at each site at the time of infaunal sampling and analyzed using the dry sieving method (Folk, 1974) with one half phi $(\varnothing)$ intervals, where each phi interval is the $-\log _{2}$ of each sieve opening used in millimeters.

Classification and normal cluster analysis were used to examine spatial differences between benthic stations and temporal changes associated with the storm. Using the ORDANA program of Bloom et al. (1977), the data were transformed $(1 \mathrm{n}(\mathrm{x}+1))$ and sites were classified by the Czekanowski similarity index. The results of group average sorting were used to construct dendrograms. Two data formats were tested: (a) replicate samples were combined and the total abundance of taxa for each sampling date was used to produce a 4entity cluster and (b) replicates were classified separately, thus 40 entities were clustered. Comparison of results from these two formats provided insight into within-habitat sampling variability.

\section{RESULTS}

\section{Water column}

Compared to pre-storm values, there were twice as many species and 6 times as many individuals collected from the effluent after the storm (Table 1). The 
Table 1. Numbers of individuals and species of infauna in water column samples collected before and after a storm

\begin{tabular}{|c|c|c|c|c|}
\hline \multirow[b]{2}{*}{ Taxon } & \multicolumn{2}{|c|}{ Pre-storm } & \multicolumn{2}{|c|}{ Post-storm } \\
\hline & $\begin{array}{l}\text { Indi- } \\
\text { viduals }\end{array}$ & $\begin{array}{l}\text { Spe- } \\
\text { cies }\end{array}$ & $\begin{array}{l}\text { Indi- } \\
\text { viduals }\end{array}$ & $\begin{array}{l}\text { Spe- } \\
\text { cies }\end{array}$ \\
\hline Amphipoda & 164 & 15 & $\cdot$ & 21 \\
\hline Cumacea & 21 & 2 & & 2 \\
\hline Mysidacea & 8 & 2 & & 1 \\
\hline Isopoda & 5 & 2 & & 4 \\
\hline Decapoda & 4 & 2 & & 4 \\
\hline Misc. Crustacea & 4 & 4 & & 4 \\
\hline Oligochaeta & 0 & 0 & 18 & 1 \\
\hline Polychaeta & 88 & 14 & 442 & 47 \\
\hline Gastropoda & 75 & 4 & 203 & 12 \\
\hline Bivalvia & 10 & 4 & 43 & 7 \\
\hline Rhynchocoela & 7 & 1 & 0 & 0 \\
\hline Platyhelminths & 4 & 1 & 3 & 1 \\
\hline Actiniaria & 1 & 1 & 0 & 0 \\
\hline Totals & 391 & 52 & 2,836 & 104 \\
\hline \multicolumn{5}{|c|}{$\begin{array}{l}\text { - Crustaceans were estimated to represent } 75 \% \text { of all } \\
\text { individuals }\end{array}$} \\
\hline
\end{tabular}

qualitative nature of the post-storm sample made statistical comparison inappropriate here. Crustaceans (mostly amphipods) and polychaetes showed the greatest increase in number of individuals and species, respectively.Gastropods, bivalves, and oligochaetes increased to a lesser extent. Following the storm, the relative abundance of crustaceans rose from approximately $50 \%$ to $75 \%$ and that of all other major taxa decreased (Table 2). However, the percent contribution of crustacean species declined due to increases in the number of polychaete and mollusc species.
Table 2. Relative abundance of major infaunal taxa in water column samples collected before and after a storm

\begin{tabular}{|lcccc|}
\hline & \multicolumn{3}{c}{ Individuals } & \multicolumn{2}{c|}{ Species } \\
Taxon & $\begin{array}{c}\text { Pre- } \\
\text { storm }\end{array}$ & $\begin{array}{c}\text { Post- } \\
\text { storm }\end{array}$ & $\begin{array}{c}\text { Pre- } \\
\text { storm }\end{array}$ & $\begin{array}{c}\text { Post- } \\
\text { storm }\end{array}$ \\
\hline Crustacea & $50.4 \%$ & $75.0 \%$ & $51.9 \%$ & $35.1 \%$ \\
Polychaeta & 22.0 & 15.6 & 27.0 & 45.2 \\
Gastropoda & 19.0 & 7.2 & 7.7 & 11.5 \\
Bivalvia & 2.6 & 1.5 & 7.7 & 6.7 \\
All others & 6.0 & 0.7 & 5.7 & 1.5 \\
- Crustaceans were too numerous to count & and were \\
estimated to represent 75\% of all individuals \\
\hline
\end{tabular}

\section{Bottom sediments}

The percentage of sediment particles greater than or equal to $3.0 \varnothing(0.125 \mathrm{~mm})$ was reduced at both stations the day after the storm (Fig. 2). Greater change occurred at the sand site, where relative increases in the larger fractions $(0.0$ to $2.0 \varnothing)$ resulted from a large decrease in the silt-clay fraction $(<5.0 \varnothing)$.

There were no significant before-after differences at either site in the mean density of individuals per core (Wilcoxon U test, p > 0.05) (Fig. 3). The number of species per core significantly decreased at the sand site but not at the Zostera site. There were stormassociated changes in the rank order of dominant taxa, although these were rearrangements rather than substitutions (Table 3). At the sand station, for example, Lumbrineris tenuis was not among the dominant taxa prior to the storm but ranked third afterward. Lyonsia

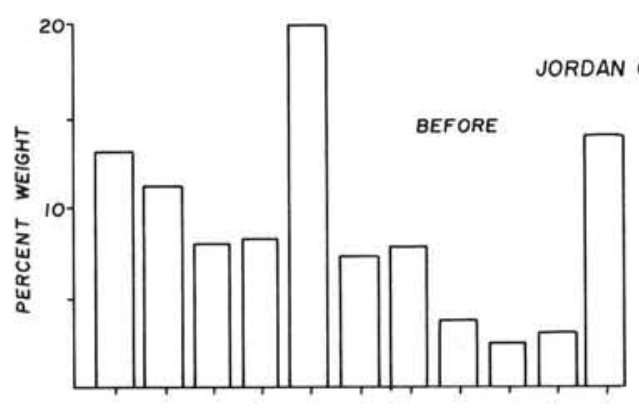

COVE SAND
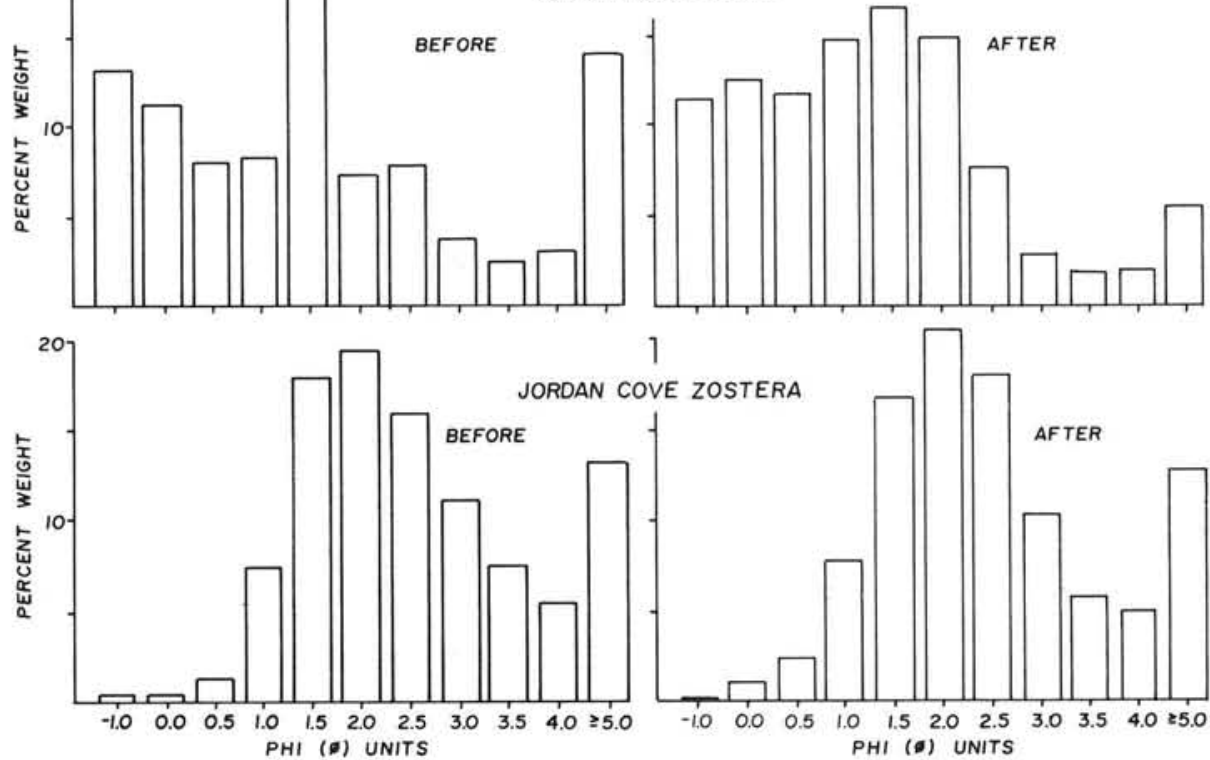

1

ZE ZOSTERA

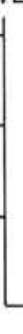

$\begin{array}{lllllllllll}-1.0 & 0.0 & 0.5 & 1.0 & 1.5 & 2.0 & 2.5 & 3.0 & 3.5 & 4.0 & 25.0\end{array}$

$\begin{array}{rrrrrr}0.0 & 0.5 & 1.0 & 1.5 & 2.0 & 2.5 \\ & \text { PHI } & \text { (.) UNITS }\end{array}$
Fig. 2. Sediment frequency histograms representing pre- and post-storm differences 


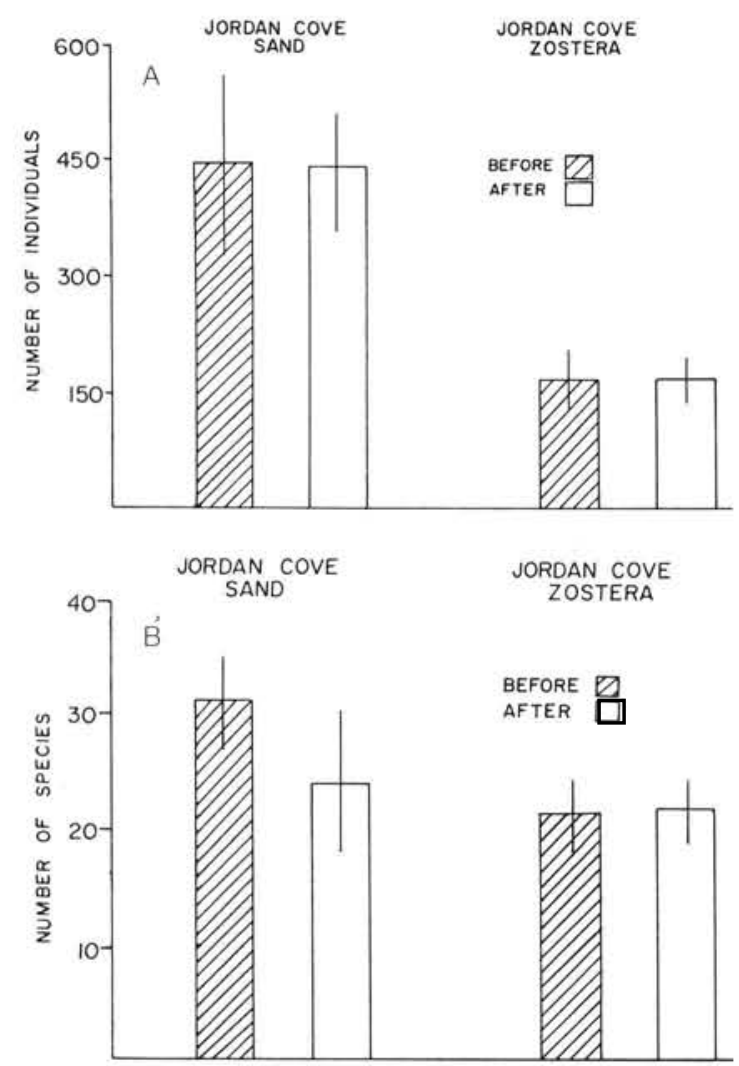

Fig. 3. Mean number ( $\pm 95 \%$ confidence limits) of individuals $(A)$ and species $(B)$ per core $\left(\right.$ area $=0.0078 \mathrm{~m}^{2}$ ) before and after Storm David

hyalina and Exogone dispar also increased in relative density after the storm. Less change occurred at the Zostera station, where only one species among the 10 most dominant was substituted afterward. Although there were pre- and post-storm differences in the abundance of all species, significant decreases occurred only in the population densities of Aricidea catherinae and Lumbrineris impatiens at the sand station and Chaetozone spp. at the Zostera station. There was a significant increase in Chaetozone spp. at the sand station after the storm. Attempts to relate changes in abundance and percent composition with the organisms' life modes were unsuccessful.

When cluster analysis was applied to the pooled replicate cores, the before and after samples grouped by site type (Fig. 4). The similarity between Zostera samples $(0.76)$ was greater than that between sand samples $(0.62)$, suggesting that the storm may have caused less change in the composition and abundance of species in the Zostera bed. (Alternatively, the Zostera community may have maintained a greater degree of spatial homogeneity.) When the analysis was expanded to compare all 40 cores, 5 clusters emerged (Fig. 5). Groups I and III were composed exclusively of samples from the sand station, with overlapping before and after samples. Similarly, both pre- and post-storm samples from the Zostera station predominated in Groups II and IV, although 2 sand samples were classified into each group. There were 2 sub-groups in Group V, each composed of before and after samples.

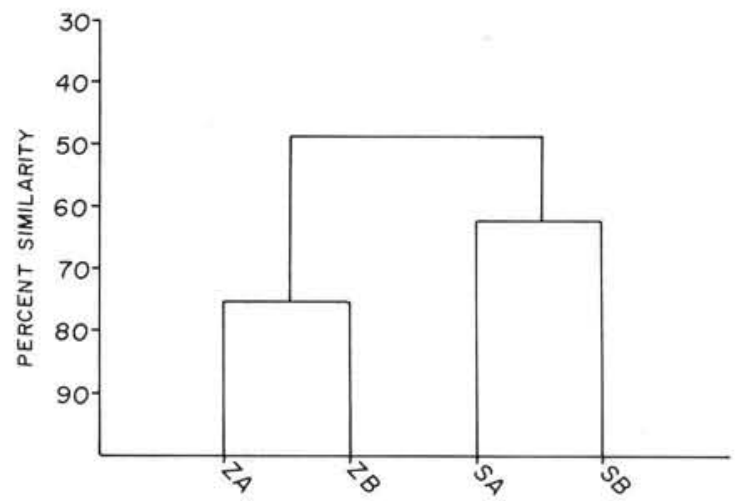

Fig. 4. Dendrogram resulting from group average clustering of combined replicates collected before and after Storm David

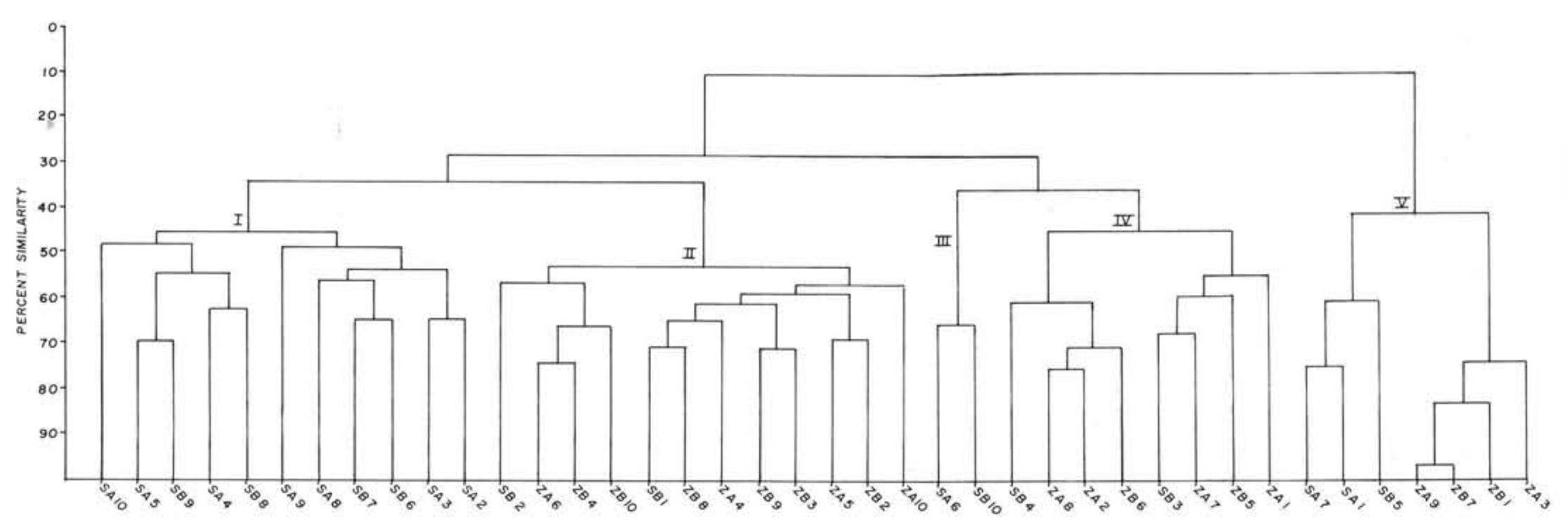

Fig. 5. Dendrogram resulting from group average clustering of samples collected before and after Storm David. See text for details of classification. S Jordan Cove Sand; Z Jordan Cove Zostera; A After; B Before; 1-10 sample number 
Table 3. Numerically dominant taxa in benthic samples collected before and after a storm. Values represent the number of organisms in 10 cores (total area $=0.078 \mathrm{~m}^{2}$ )

\begin{tabular}{|c|c|c|c|c|c|c|}
\hline \multirow{2}{*}{$\begin{array}{l}\text { Station Jordan Cove Sand } \\
\text { Taxon }\end{array}$} & \multicolumn{2}{|c|}{ Rank } & \multicolumn{2}{|c|}{ Abundance } & \multicolumn{2}{|c|}{ \% Composition } \\
\hline & Before & After & Before & After & Before & After \\
\hline Mediomastus ambiseta & 1 & 2 & 1,531 & 1,347 & 35.0 & 31.6 \\
\hline Oligochaeta & 2 & 1 & 1,237 & 1,744 & 28.3 & 40.9 \\
\hline Aricidea catherinae & 3 & 4 & 434 & $162^{\circ}$ & 9.9 & 3.8 \\
\hline Polycirrus eximius & 4 & 5 & 210 & 156 & 4.8 & 3.7 \\
\hline Lumbrineris impatiens & 5 & - & 209 & $-\cdots$ & 4.8 & - \\
\hline Chaetozone spp. & 6 & 6 & 92 & $128^{*}$ & 2.1 & 3.0 \\
\hline Microphthalmus aberrans & 7 & 7 & 80 & 83 & 1.8 & 1.9 \\
\hline Capitella spp. & 8 & 9 & 71 & 52 & 1.6 & 1.2 \\
\hline Tharyx spp. & 9 & - & 62 & - & 1.4 & - \\
\hline Parapionosyllis longicirrata & 10 & - & 55 & - & 1.3 & - \\
\hline Lumbrineris tenuis & $-\cdots$ & 3 & - & 181 & - & 4.2 \\
\hline Lyonsia hyalina & - & 8 & - & 54 & - & 1.3 \\
\hline Exogone dispar & - & 10 & - & 38 & - & 0.9 \\
\hline \multicolumn{7}{|l|}{$\begin{array}{l}\text { Station Jordan Cove Zostera } \\
\text { Taxon }\end{array}$} \\
\hline Aricidea catherinae & 1 & 2 & 448 & 335 & 26.4 & 20.2 \\
\hline Oligochaeta & 2 & 1 & 441 & 482 & 26.0 & 29.1 \\
\hline Chaetozone spp. & 3 & 3 & 312 & $190^{*}$ & 18.4 & 11.5 \\
\hline Pygospio elegans & 4 & 4 & 104 & 112 & 6.1 & 6.8 \\
\hline Capitella spp. & 5 & 6 & 67 & 84 & 3.9 & 5.1 \\
\hline Polydora ligni & 6 & 8 & 45 & 34 & 2.6 & 2.0 \\
\hline Exogone hebes & 7 & 5 & 36 & 111 & 2.1 & 6.7 \\
\hline Polycirrus eximius & 8 & 9 & 27 & 30 & 1.6 & 1.8 \\
\hline Microprotopus raneyi & 9 & - & 21 & - & 1.2 & - \\
\hline Listriella barnardi & 10 & 10 & 18 & 22 & 1.0 & 1.3 \\
\hline Protodorvillea gaspeensis & $-\cdots$ & 7 & - & 44 & - & 2.6 \\
\hline
\end{tabular}

\section{DISCUSSION}

These results seem contradictory; there were large post-storm increases in the number and types of infauna in the water column samples but no commensurate change in the benthic infaunal communities, i. e. no mass mortality nor large-scale redistribution of organisms. Several explanations may account for the observed increase in benthic infauna in water column samples. First, the mobilization of benthos may not have increased above pre-storm levels. Instead, prolonged southerly and westerly winds may have concentrated organisms in Niantic Bay following their transport from other areas in Long Island Sound. In fact, water column samples contained infaunal taxa which have never been found in benthic cores taken in the vicinity of Millstone Point, including samples in adjacent Niantic Bay (e. g. Magelona rosea and Chone spp.). This suggests that these organisms were transported over wide ranges in the order of kilometers.

Second, the storm may have significantly mobilized benthic organisms. There were increased numbers and species of shelled molluscs collected after the height of the storm (e. g. Mysella planulata and Solemya velum). It seems unlikely that these heavy and presumably fast-sinking organisms would remain in the water column sufficiently long to be transported across the Sound. More probably, storm-induced disturbance of the shallow ( 7 to $8 \mathrm{~m}$ ), silty sediment of nearby Niantic Bay created localized concentrations of molluscs in the water column. Indeed, all molluscs collected in the effluent are also found in benthic core samples from this area.

Third, environmental cues provided by the storm may have elicited in some benthic organisms an active response of some sort which resulted in their movement into the water column. Other investigators have reported active nocturnal swimming, unrelated to reproduction, by polychaetes (Dean, 1978a, b; Graham and Creaser, 1978), and density-dependent vertical migration by haustoriid amphipods (Croker, 1968; Grant, 1980). 
Samples collected at the benthic infaunal stations indicated little post-storm differences in terms of community density, species number, and dominant taxa. Cluster analysis revealed consistent temporal overlap at both stations, suggesting that if any small-scale changes in species composition and abundance were caused by the storm, then they were no greater in magnitude than the intrinsically contagious distribution of organisms in these communities.

If the storm did affect these benthic communities, then the extent of change may have been influenced by substrate. The sediments and community in the Zostera bed changed less than their counterparts at the silty sand station, possibly due to enhanced sediment stability effected by eelgrass roots, rhizomes, and blades (Ginsburg and Lowenstam, 1958; but see Eckman et al., 1981). In addition, the Zostera site is located in an area more sheltered from waves generated by southwesterly winds.

The lack of outstanding change in the benthic communities was unanticipated. In Long Island Sound, significant storm disturbance of bottom sediments (and presumably of the communities inhabiting them) occurs to water depths of $20 \mathrm{~m}$ (McCall, 1978). Although the sediment silt - clay fraction decreased at both stations, the infauna emerged essentially unscathed - why? Storms of David's magnitude are not common but have occurred in the evolutionary past of these organisms. Therefore, many of them probably exhibit behaviours which mitigate the scouring effects of storm-amplified currents and waves. For example, they may burrow deeper in the sediments or move downward in their tubes or galleries. Such behavior, coupled with the relatively protected locations of the benthic infauna sites, may have reduced the impact of the storm on these communities.

To reconcile the apparently contradictory results of the benthic and planktonic sampling, we presume that the storm was more catastrophic to distant benthic communities. In those areas, organisms were carried or moved themselves into the water column, and were transported into the sampling area.

Field experiments have demonstrated recolonization of disturbed areas by adult meiofauna (Bell and Sherman, 1980; Sherman and Coull, 1980; Thistle, 1980; Palmer and Brandt, 1981) and adult macrofauna (Dauer and Simon, 1976; Santos and Simon, 1980; Grant, 1981; Dobbs, unpubl.). Although within the sediment, movement of benthos undoubtedly contributes to recolonization, water column transport may provide a more rapid and possibly more important mode, especially in the case of large-scale disturbance. As shown in this study, the turbulent conditions associated with storms can suspend benthic infauna, even large species, and apparently move them over a relatively great distance.
Therefore, storms may provide a mechanism for widescale redistribution of ostensibly obligate infauna. If turbulence-suspended organisms were shown to settle in a new area, live and reproduce, then the importance of storms to benthic population dynamics would be unequivocal.

Acknowledgements. We gratefully acknowledge the assistance of members of the benthic, fisheries, and plankton groups, Northeast Utilities Environmental Laboratory, in the collection and processing of samples. We thank R. Larsen for programming advice and G. Johnson for graphics preparation. We appreciate critical comments by $\mathrm{R}$. Larsen und $\mathrm{M}$. Keser on an earlier draft of this manuscript.

\section{LITERATURE CITED}

Barnett, B. E. (1981). An assessment of the effects of severe weather on the intertidal fauna of the Humber estuary (South Bank), UK-consequences for biological monitoring. Mar. environ. Res. 5: 51-57

Bell, S. S., Sherman, K. M. (1980). A field investigation of meiofaunal dispersal: tidal resuspension and implications. Mar. Ecol. Prog. Ser. 3: 245-249

Bloom, S. A., Santos, S. L., Field, J. G. (1977). A package of computer programs for benthic community analyses. Bull. mar. Sci. 27: 577-580

Boesch, D. F., Diaz, R. J., Virnstein, R. W. (1976). Effects of tropical storm Agnes on soft-bottom macrobenthic communities of the James and York estuaries of the lower Chesapeake Bay. Chesapeake Sci. 17: 246-259

Croker, R. A. (1968). Distribution and abundance of some intertidal sand beach amphipods accompanying the passage of two hurricanes. Chesapeake Sci. 9: 157-162

Dauer, D. M., Simon, J. L. (1976). Habitat expansion among polychaetous annelids repopulating a defaunated marine habitat. Mar. Biol. 37: 169-177

Dean, D. (1978a). The swimming of bloodworms (Glycera spp.) at night, with comments on other species. Mar. Biol. 48: $99-100$

Dean, D. (1978b). Migration of the sandworm Nereis virens during winter nights. Mar. Biol. 45: 165-173

Dexter, D. M. (1967). Distribution and niche diversity of haustoriid amphipods in North Carolina. Chesapeake Sci. 8: 187-192

Eagle, R. A. (1975). Natural fluctuations in a soft bottom benthic community. J. mar. biol. Ass. U. K. 55: 865-878

Eckman, J. E., Nowell, A. R. M., Jumars, P. A. (1981). Sediment destabilization by animal tubes. J. mar. Res. 39: 361-374

Folk, R. L. (1974). Petrology of sedmentary rocks. Hemphill, Austin, Texas

Ginsburg, R. N., Lowenstam, H. A. (1958). The influence of marine bottom communities on the depositional environment of sediments. J. Geol. 66: 310-318

Glémarec, M. (1979). Les fluctuations temporelles des peuplements benthiques liées aux fluctuations climatiques. Oceanol. Acta 2: 365-371

Graham, J. J., Creaser, E. P., Jr. (1978). Tychoplanktonic bloodworm, Glycera dibranchiata, in Sullivan Harbor, Maine. Fish. Bull. U. S. 76: 480-483

Grant, J. (1980). A flume study of drift in marine infaunal amphipods (Haustoriidae). Mar. Biol. 56: 79-84 
Grant, J. (1981). Sediment transport and disturbance on an intertidal sandflat: infaunal distribution and recolonization. Mar. Ecol. Prog. Ser. 6: 249-255

McCall, P. L. (1977). Community patterns and adaptive strategies of the infaunal benthos of Long Island Sound. J. mar. Res. 35: 221-266

McCall, P. L. (1978). Spatial-temporal distributions of Long Island Sound infauna: the role of bottom disturbance in a nearshore marine habitat. In: Wiley, M. L. (ed.) Estuarine interactions. Academic Press, New York, p. 191-219

Palmer, M. A., Brandt, R. R. (1981). Tidal variation in sediment densities of marine benthic copepods. Mar. Ecol. Prog. Ser. 4: 207-212

Rachor, E., Gerlach, S. A. (1978). Changes of macrobenthos in a sublittoral sand area of the German Bight, 1967 to 1975. Rapp. P.-v. Réun. Cons. int. Mer 172: 418-431

Rees, E. I. S., Nicholaidou, A., Laskaridou, P. (1977). The effects of storms on the dynamics of shallow water associa- tions. In: Keegan, B. F., Ceidigh, P. O., Boaden, P. J. S. (eds.) Biology of benthic organisms. Pergamon, New York, p. $465-474$

Santos, S. L., Simon, J. L. (1980). Marine soft-bottom community establishment following annual defaunation: larval or adult recruitment? Mar. Ecol. Prog. Ser. 2: 235-241

Sherman, K. M., Coull, B. C. (1980). The repsonse of meiofauna to sediment disturbance. J. exp. mar. Biol. Ecol. 46: $59-71$

Thistle, D. (1980). The response of a harpacticoid copepod community to a small scale natural disturbance. J. mar. Res. 38: 381-395

Wolff, W. J., Sandee, A. J. J., de Wolf, L. (1977). The development of a benthic ecosystem. Hydrobiologia 52: 107-115

Yeo, R. K.; Risk, M. J. (1979). Intertidal catastrophes: effect of storms and hurricanes on intertidal benthos of the Minas Basin, Bay of Fundy. J. Fish. Res. Bd Can. 36: 667-669

This paper was submitted to the editor; it was accepted for printing on October 14, 1982 